\title{
Relationship between self-reported vision and vision function measured in the first ophthalmologic evaluation
}

\author{
Relação entre visão referida e visão aferida \\ na primeira avaliação oftalmológica
}

Heloísa Silva de Avón, Luís Antônio Gorla Marcomini²

\begin{abstract}
Purpose: Compare self-reported vision with visual function measured in the first ophthalmologic evaluation and correlate the findings with the following variables: age, gender, educational status and visual acuity. Methods: Patients files treated in the first ophthalmologic evaluation at a private clinic were raised. Visual function measured at the appointment was carried out using the Snellen chart. Data has been tabulated in an Excel spreadsheet and subjected to statistical analysis (Fisher's Exact test) in order to verify the influence of the variables according to $p$-value $<0.05$. Results: Out of 300 patients evaluated, $66(22 \%)$ had low vision (LV) at the first ophthalmologic evaluation, 46 (69.69\%) of them had reported LV before the exam and 20 (30.30\%) had not. There was no statistical difference in the presence $(p=0.78)$ or in the perception of $L V(p=0.30)$ in relation to gender. All patients over 75 years-old had LV, which was significant in relation to the different age groups $(p<0.0001)$. There was no significant difference in relation to the perception of LV between age groups $(p=0.166)$. Conclusion: Gender and educational status were not statistically significant. Age and visual acuity levels were significant according to the distribution of LV in those over 75 years-old and people with severe vision loss, respectively.
\end{abstract}

Keywords: Vision low; Age groups; Gender identity; Educational status; Visual acuity

\section{ResUMO}

Objetivo: Comparar a acuidade visual referida com a aferida no primeiro exame oftalmológico e correlacionar os achados com as variáveis: idade, gênero, escolaridade e nível de acuidade visual. Métodos: Foram levantadas fichas de pacientes atendidos em primeira consulta oftalmológica em uma clínica particular no período de um ano. Comparou-se a acuidade visual referida na história clínica com a obtida no exame oftalmológico. Para a tomada da acuidade visual utilizou-se a tabela de Snellen. Os dados foram tabulados em planilha Excel e submetidos à análise estatística. Adotou-se o nível de significância p=0,05. Resultados: Dos 300 pacientes avaliados, 66 (22\%) apresentaram baixa visão (BV) ao exame oftalmológico; destes 46 (69,69\%) referiram BV antes do exame e $20(30,30 \%)$ não. Em relação ao gênero, não houve diferença estatística na presença (p=0,78) nem na percepção de BV $(p=0,30)$. Todos os pacientes acima dos 75 anos tinham BV $(p<0,0001)$; não houve diferença estatística significativa em relação à percepção de BV entre as faixas etárias $(\mathrm{p}=0,166)$. O nível de escolaridade não influenciou na presença de BV (p=0,112) e nem na percepção de BV $(\mathrm{p}=0,945)$. Com relação ao nível da acuidade visual, todos os pacientes com perda visual severa haviam se apercebido deste fato e referiram BV na anamnese. Conclusão: Não houve diferença estatística significativa quanto à presença nem a percepção de BV entre gênero e escolaridade. No entanto, houve diferença estatística na presença de BV em relação às faixas etárias e na percepção de BV em relação ao nível de acuidade visual.

Descritores: Baixa Visão; Grupos etários; Identidade de gênero; Escolaridade; Acuidade visual

${ }^{1}$ Graduation in Medicine, Pontifícia Universidade Católica de Campinas, Campinas, SP, Brazil.

${ }^{2}$ Department of Medicine, Center for Biological and Health Sciences, Universidade Federal de São Carlos, São Carlos, SP, Brazil The authors declare no conflicts of interests.

Received for publication 05/08/2015 - Accepted for publication 10/09/2015 


\section{INTRODUCTION}

$\mathbf{M}$ ost of the information we receive from the external environment is through vision. Thus, the integrity of this sense is key for the maintenance of life and its quality. ${ }^{(1)}$

There are four levels of visual function according to the International Classification of Diseases (ICD-10) revised in 2006: normal vision; moderate disability; severe disability and blindness. Moderate and severe disabilities are grouped under the term "low vision", which can include both changes in the visual acuity (VA), the visual field, or both. ${ }^{(2,3)}$

Low vision (LV) is a worldwide public health problem, as the decrease in the VA leads to impaired quality of life. ${ }^{(4,5)}$ Furthermore, several articles indicate that the prevalence of patients with low vision has increased significantly, especially among the elderly. ${ }^{(6)}$

Data from the World Health Organization (WHO) show that in the world there are 285 million visually impaired people, of whom 39 million are blind and 246 million have LV. ${ }^{(2)}$

Literature shows few articles relating to vision quality perceived by the patient with the visual acuity assessed in the appointment. As far as we know none of these articles relates to the visual acuity effectively obtained in the first ophthalmologic appointment, and the VA is reported by the patient. The importance of making this study in the first ophthalmologic consultation is that patients who have already undergone previous ophthalmic examinations become able to carry out selfexamination and, therefore, can realize more easily the low vision.

Laitinen et al. have related the visual acuity levels to the quality of vision reported by the patients. They achieved a moderate correlation, but statistically significant $(p<0.0001)$ when comparing the quality of the self-reported vision of the patients to the one found in the assessment of visual acuity. Patients with good or moderate farsighted visual acuity have a level of visual acuity of $0.8(20 / 25)$ or better. The prevalence of visual impairments increased significantly with age $(\mathrm{p}<0.001)$, especially in the group above 65 years. There was no gender difference for farsighted visual acuity, but the decline of nearsight was significantly more common in men than women. ${ }^{(7)}$

A study conducted in the United States of America assessed 31,044 not institutionalized adults above 18 years old, and related self-reported impairments to eye diseases. A prevalence of visual impairment of $9.3 \%$ was found, including $0.3 \%$ with blindness. The most prevalent diseases were: cataract $(8.6 \%)$, glaucoma $(2 \%)$, macular degeneration $(1.1 \%)$ and diabetic retinopathy $(0.7 \%)$. ${ }^{(4)}$

Kim et al. conducted a study in Korea for more than ten years in order to characterize and assess patients with low vision. Among the participants aged between 11 to 20 years of age (18.1\%), optic atrophy $(28.3 \%)$ was the leading cause of low vision. They noted that the number of elderly patients with low vision is increasing, and macular degeneration (age-related or associated to diabetes) is becoming the leading cause of low vision in this population $(\mathrm{p}<0.05) .{ }^{\left({ }^{8}\right)}$

In a study performed in the Ophthalmology Department of the Federal University of São Paulo (UNIFESP), a weak correlation was found between self-reported visual quality and the measure of visual acuity of the patients. This study was conducted by means of questionnaires to patients attending the ophthalmology service of that institution. ${ }^{(9)}$
As reported above, the study conducted at the UNIFESP found a weak correlation between the self-reported vision quality and the one measures at the appointment, showing that often it is not easy for the patient to recognize the presence of low vision. In our clinical practice we have found cases in which the patient gets to the office dissatisfied with "failing" the eye examination for revalidation of the National Driver's License $(\mathrm{CNH})$ because they do not believe they are suffering from low vision. This is in accordance with the results obtained in the study of UNIFESP. ${ }^{(9)}$

Given the above, the importance of regular eye exams is clear both for early diagnosis of diseases of the visual system and for the detection of low vision.

Thus, we decided to conduct a study to determine the level of agreement between the quality of vision perceived by the patient and the visual acuity (no optical correction) measured in the first ophthalmologic appointment, and to see if there was any variation of this index according to the following variables: age, gender, education and level of visual acuity.

\section{Methods}

The files of patients seen at the first ophthalmologic appointment at a private clinic in the city of Araraquara were analyzed in the period from January 2, 2012 to December 30, 2013. Data on age, sex, gender, reason for consultation, referred acuity visual, measure of uncorrected visual acuity, refraction and pathologies were compiled in an Excel ${ }^{\circledR}$ spreadsheet.

The measure of visual acuity was performed using the Snellen chart.

Regarding education, we considered the grade already completed. Patients with incoherent responses that compromise the reliability of the visual acuity test were excluded, as well as those under seven years of age.

In our study we considered the acuity of the best eye (Chart 1).

\section{Chart 1}

Visual acuity levels according to CID 10, 2006

\begin{tabular}{lc}
\hline Vision & Degree \\
\hline Normal vision & $\geq 0.8$ \\
Mild visual losse & $<0.8 \mathrm{a} \geq 0.3$ \\
Moderate visual loss & $<0.3 \mathrm{a} \geq 0.1$ \\
Severe visual loss (legal blindness) & $<0.1$ \\
\hline
\end{tabular}

All data were entered into an Excel spreadsheet and subjected to statistical analysis (Fisher exact test). The significance level was five percent.

\section{RESULTS}

Of the 300 patients assessed, 66 (22\%) had low vision to the eye examination; of these, $46(69.69 \%)$ reported low vision before the exam, and $20(30.30 \%)$ did not. Interestingly there were 24 individuals $(8 \%)$ complaining of poor vision or blurred vision, presenting uncorrected VA e" 0.8 in both eyes, i.e., normal vision.

Regarding gender, of the 300 participants, 130 (43\%) patients were male, and 170 patients (57\%) were female (Figure 1). 
GENDER

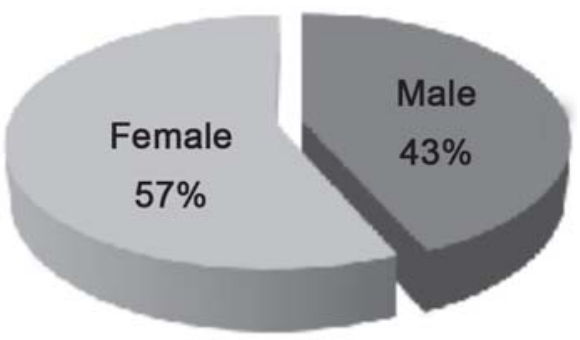

Figure 1: Distribution of the population sample by gender

Among participants with low vision, 30 (45.5\%) were males and $36(54.5 \%)$ were females. There was no statistical difference in the presence of low vision between men and women $(\mathrm{p}=0.78)($ Table 1$)$.

Table 1

\section{Distribution of patients regarding the presence of low vision in the eye exam according to gender}

\begin{tabular}{lccc}
\hline Gender & \multicolumn{2}{c}{ Low vision } & \\
& No & Yes & Total \\
\hline Male & 100 & 30 & 130 \\
Female & 134 & 36 & 170 \\
\hline Total & $\mathbf{2 3 4}$ & $\mathbf{6 6}$ & $\mathbf{3 0 0}$ \\
\hline
\end{tabular}

In relation to the perception of low vision, there was no difference between genders $(\mathrm{p}=0.06)$. Of the 30 men with low vision, 13 did not realize and 17 realized they had low vision before the ophthalmologic appointment. In the case of women, 7 did not realize and 29 realized (Figure 2).

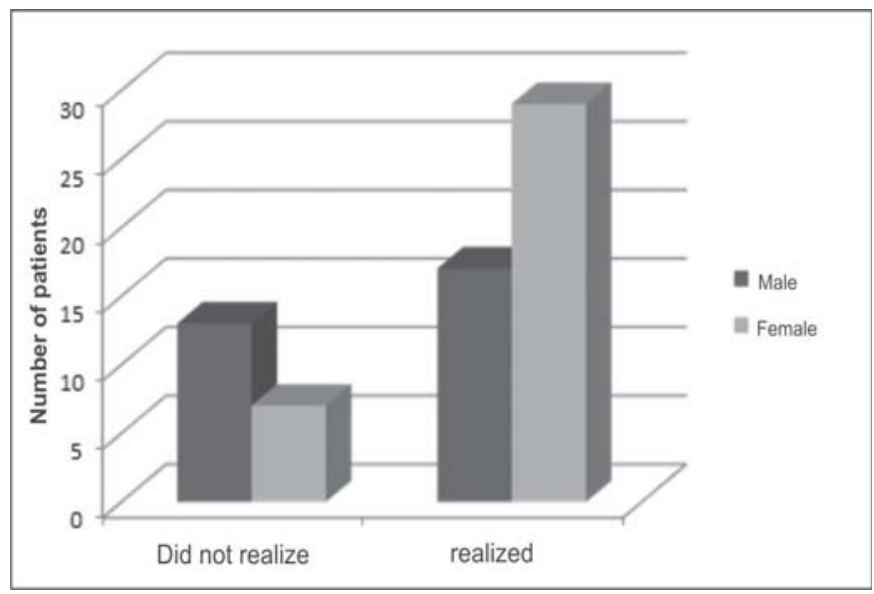

Figure 2: Distribution of patients by gender in relation to the perception or not of low vision.

All patients above 75 years had low vision, and here there was a statistically significant difference compared to other age groups $(\mathrm{p}<0.0001)$. The distribution of low vision by age group can be seen in the table below (Table 2).
Table 2

\section{Distribution of patients regarding the presence of low vision in the eye exam according to the age group}

\begin{tabular}{lrrr}
\hline Age group & \multicolumn{2}{c}{ Low vision } & \\
& No & Yes & Total \\
\hline $7 \mathrm{a} \geq 25$ & 78 & 27 & 105 \\
$>25 \mathrm{a} \geq 50$ & 110 & 16 & 126 \\
$>50 \mathrm{a} \geq 75$ & 46 & 10 & 56 \\
$<75$ & 0 & 13 & 13 \\
\hline Total & $\mathbf{2 3 4}$ & $\mathbf{6 6}$ & $\mathbf{3 0 0}$ \\
\hline
\end{tabular}

Among the patients with low vision and regarding the perception of this fact prior to the appointment, the following results are shown according to the age group: from 7 to 24 years, five did not realize and 22 realized; from 25 to 50 years, five did not realize and 11 realized; from 50 to 75 years 3 did not realize and 7 realized; and over 75 years 7 did not realize and 6 realized. There was no statistically significant difference in relation to the perception of low vision among the different age groups $(\mathrm{p}=0.166)$ (Figure 3$)$.

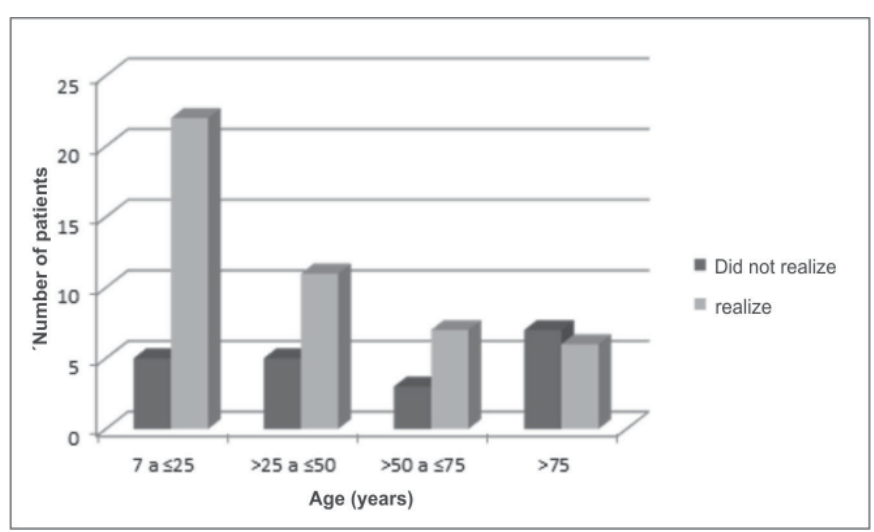

Figure 3: Distribution of patients by age group in relation to the perception or not of low vision.

There was no statistically significant difference $(\mathrm{p}=0.112)$ in relation to the distribution of low vision according to the level of education (Table 3 ).

Table 3

Distribution of patients regarding the presence of low vision in the eye exam according to the level of education

\begin{tabular}{lccc}
\hline Education & \multicolumn{2}{c}{ Low vision } & \\
& No & Yes & Total \\
\hline Iliterate & 2 & 1 & 3 \\
Literate & 58 & 19 & 77 \\
Elementary School I and II & 70 & 28 & 98 \\
High school & 83 & 15 & 98 \\
Graduation & 21 & 3 & 24 \\
\hline Total & $\mathbf{2 3 4}$ & $\mathbf{6 6}$ & $\mathbf{3 0 0}$ \\
\hline
\end{tabular}

Surprisingly there was no statistically significant difference in relation to the perception of low vision $(\mathrm{p}=0.945)$, considering the level of education. From the three illiterate patients, one realized he had low vision before an eye appointment, and two did not. Among the literate patients, 12 realized that they had 
low vision and seven did not. Among those with elementary school, 20 realized and eight did not realize they had low vision. Eleven patients with high school realized they had low vision, and four did not. From those graduated, two realized and one did not (Figure 4).

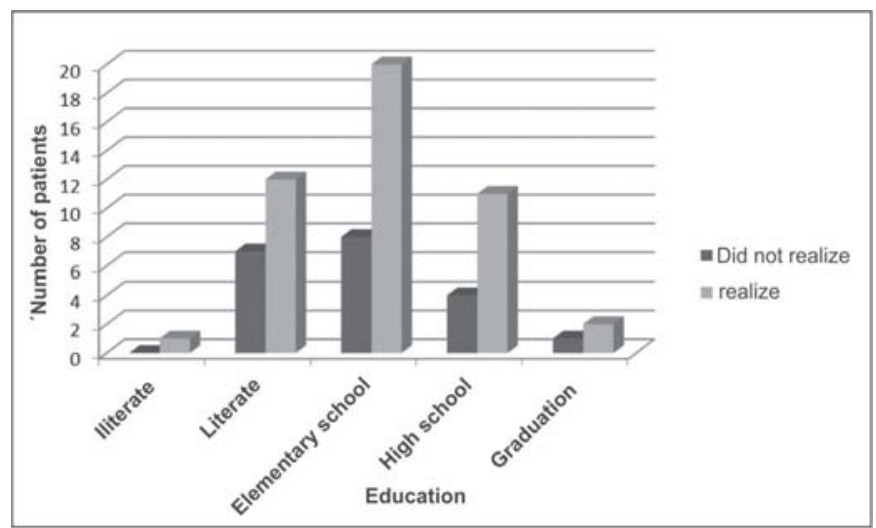

Figure 4: Distribution of patients in relation to the perception or not of low vision according to the level of education.

Regarding the level of visual acuity, although there were no significant differences between categories, all patients with severe visual loss had realized it before tha appointment (Table 4).

Table 4

\section{Distribution of patients in relation to the perception of low vision in prior to the eye examination according to the level of visual acuity}

\begin{tabular}{|c|c|c|c|c|}
\hline \multirow{2}{*}{ Vision } & & \multicolumn{3}{|c|}{ Perception of Low vision } \\
\hline & & No & Yes & Total \\
\hline Mild visual loss take & $<0.8 \mathrm{a} \geq 0.3$ & 11 & 29 & 40 \\
\hline Moderate visual loss & $<0.3 \mathrm{a} \geq 0.1$ & 9 & 14 & 23 \\
\hline Severe visual loss $<0$ & & 0 & 3 & 3 \\
\hline Total & & 20 & 46 & 66 \\
\hline
\end{tabular}

\section{DisCUSSION}

According to our study, $78 \%$ of the patients had normal vision at the eye examination. A study conducted in Finland by Laitinen et al in an adult population of 6,663 individuals had value similar to ours: $87.4 \%$ of patients with normal vision. In the Finnish study, among patients with low vision, $0.5 \%$ were blind. ${ }^{(7)}$ In our study, $4.5 \%$ were legally blind (VA in the best eye $<0.1$ ), and all of them reported low vision before the eye examination. This percentage difference of blind patients may be due to the smaller size of our sample, the fact of our sample had been obtained among participants looking for ophthalmology, and also due to the socio-economic conditions, since Finland is a developed country and Brazil is a developing country.

In our study, the self-reported visual quality did not have direct correspondence with the visual acuity. This is in line with the study of Cinoto conducted in 2006 in São Paulo, which compared the quality of self-reported vision to the VA in the elderly population (806 individuals) above 60 years. However, the Finnish study showed a moderate but significant correlation between the reported and measured VA in eye examination. ${ }^{(7,9)}$ Similar results between our work and the work of Cinoto, and different ones between ours and Laitinen's are maybe due to inherent similarities (in the first case) and differences (in the second) in: the sample types, study designs and socio-economic status of the populations from which the samples were extracted.

A study conducted in South Korea with individuals from 5 to 90 years old obtained a higher LV prevalence in men than in women. ${ }^{(8)}$ In our study, men and women were equally affected by low vision $(\mathrm{p}=0.06)$. Maybe if we had a larger sample this result would be different and perhaps coinciding with the Korean work.

Regard to education, the results were surprising, as mentioned before. There was no statistical difference in relation to the perception of low vision according to education. We expected that the higher the education, the greater the coincidence would be between the self-reported vision and the measured one, but it didn't happen. Perhaps this had happened because our sample contained few illiterate (only three individuals). In a study published by El-Gasim et al. in the magazine Ophthalmology in 2012, they obtained the result of people with less education having a more disparate self-perception of the reality, both for those who had low cision and said they saw well and for those who could see well and said had low vision. ${ }^{(10)}$

Regarding age groups, approximately $90 \%$ of individuals with visual impairment live in developing countries, and of those $65 \%$ are 50 years or older, according to the WHO. ${ }^{(2)}$ That is, visual acuity decreases significantly with age. In our study, all patients above 75 years had low vision, although there was no statistically significant difference between this group and those of other age groups regarding the perception of low vision. Both the Finnish and the Korean studies showed a more intense impairment of the visual function in the older age groups. A British study published in 2005 in the journal Family Practice by Iliffe et al. also concluded that the visual impairment increases with age, particularly $>65$ years. ${ }^{(11)}$ However, this study did not show any difference regarding the prevalence of low vision in relation to gender and education. ${ }^{(7,8,11)}$

\section{CONCLUSION}

The results of our study support the conclusion that there was no statistically significant difference in the presence nor the perception of LV between men and women. All patients above 75 years had LV. However, there was no statistically significant difference in the perception of LV among different age groups. There was no statistically significant difference in the distribution of low vision according to the education. Contrary to what we thought, there was no statistically significant difference in relation to the perception of low vision, considering the level of education. Regarding the level of visual acuity, although there were no statistically significant differences between categories, all patients with severe visual loss complained of low vision.

\section{ACKNOWLEDGEMENT}

To the Federal University of São Carlos for the opportunity to carry out this work. 


\section{RefERENCES}

1. Gayton AC, Hall JE. Tratado de fisiologia médica. 12a ed. Rio de Janeiro: Sauders Elsevier; 2011.

2. World Health Organization. Visual impairment and blindness [Internet]. [cited 2015 Sept 7]. Available from: http:// www.who.int/mediacentre/factsheets/fs282/en/

3. Machado A. Neuroanatomia funcional. 2a ed. Rio de Janeiro: Atheneu; 2000.

4. Ryskulova A, Turczyn K, Makuc DM, Cotch MF, Klein RJ, Janiszewski R. Self-reported age-related eye diseases and visual impairment in the United States: Results of the 2002 National Health Interview Survey. Am J Public Health. 2008;98(3):454-61.

5. Massof RW, Deremeik JT, Park WL, Grover LL. Self-reported importance and difficulty of driving in a low-vision clinic population. Invest Ophthalmol Vis Sci. 2007;48(11):4955-62.

6. Stevens GA, White RA Flaxman SR, Price H, Jonas JB, Keeffe J, et al. Global prevalence of vision impairment and blindness: Magnitude and temporal trends, 1990-2010. Ophthalmology. 2013;120(12):2377-84.

7. Laitinen A, Koskinen S, Härkänen T, Reunanen A, Laatikainen L, Aromaa A. A nationwide population-based survey on visual acuity, near vision, and self-reported visual function in the adult population in Finland. Ophthalmology. 2005;112(12):2227-37.
8. Kim JH, Joo KS, Moon NJ. Characteristics of 681 low vision patients in Korea. J. Korean Med Sci. 2010; 25(8):1217-21.

9. Cinoto RW, Berezovsky A. Comparação entre qualidade de visão auto-relatada e acuidade visual em população idosa de baixa renda na cidade de São Paulo. Arq Bras Oftlamol. 2006;69(1):17-22.

10. El-Gasim M, Munoz B, West SK, Scott AW.Discrepancies in the concordance of self-reported vision status and visual acuity in the salisbury eye evaluation study. Ophthalmology. 2012;29(6):997-1003.

11. Iliffe S, Kharicha K, Harari D, Swift C, Gillmann G, Stuck A. Selfreported visual function in healthy older people in Britain: an exploratory study of associations with age, sex, depression, education and income. Fam Pract. 2005;22(6):585-90.

\section{Corresponding author:}

Heloísa Silva de Avó

Alameda das Pitangueiras, 97 Parque Faber São Carlos - SP

E-mail: heloisa.avo@gmail.com 